\title{
Effects of treated agro-industrial wastewater irrigation on tomato processing quality
}

\author{
Giuseppe Gatta, Angela Libutti, Anna Gagliardi, Grazia Disciglio, Luciano Beneduce, \\ Mariangela d'Antuono, Michele Rendina, Emanuele Tarantino \\ Department of Agricultural Food and Environmental Science, University of Foggia, Italy
}

\begin{abstract}
This study was designed to determine the qualitative and microbiological impact of two different sources of irrigation water on tomato fruit: groundwater (GW), as the control, and treated agro-industrial wastewater (SW). The mean tomato fruit quality parameters of dry matter, weight, diameter, colour index, $\mathrm{pH}$, soluble solids content, titratable acidity, $\mathrm{Ca}^{2+}$ and $\mathrm{Na}^{+}$content were not significantly affected by the different water treatments. Conversely, $\mathrm{NO}_{3}{ }^{-}$contents was sig-

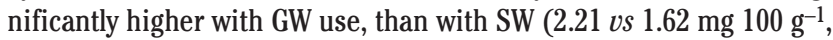
respectively; $\mathrm{P} \leq 0.05)$. The microbial quality of the tomato fruit was not significantly different across the GW and SW treatments, with no Salmonella spp. isolated from any of the fruit, and the faecal indicators always below $10 \mathrm{CFU} \mathrm{g}^{-1}$. These data show that agro-industrial treated wastewater can be used for irrigation for industrial tomato production once the long-term effects on the agroecosystem have been defined.
\end{abstract}

Correspondence: Giuseppe Gatta, Department of Agricultural Food and Environmental Science, University of Foggia, via Napoli 25, 71121 Foggia, Italy.

Tel.: +39.088.1589238

E-mail: giuseppe.gatta@unifg.it

Key words: Agro-industrial wastewater; faecal indicator; processing tomato; water quality.

Acknowledgements: this study was part of the Project In.Te.R.R.A, which is co-funded by the Italian Ministry of Universities and Research (MIUR), within the Italian PON/Ricerca e Competitività 2007-2013 Programme.

Conference presentation: SIA XLIII Congress, Pisa, 2014.

Received for publication: 28 November 2015.

Revision received: 5 February 2015.

Accepted for publication: 7 February 2015.

(C) Copyright G. Gatta et al., 2015

Licensee PAGEPress, Italy

Italian Journal of Agronomy 2015; 10:632

doi:10.4081/ija.2015.632

This article is distributed under the terms of the Creative Commons Attribution Noncommercial License (by-nc 3.0) which permits any noncommercial use, distribution, and reproduction in any medium, provided the original author(s) and source are credited.

\section{Introduction}

The use of wastewater for irrigation is increasingly being considered as a technical solution to minimise soil degradation, to restore the nutrient content of the soil, and to increase water supplies to agriculture. Treated wastewater is normally used for irrigation purposes in countries suffering from water shortages, to narrow the gap between supply and demand. The application of treated wastewater to croplands is an attractive option also for wastewater disposal, particularly as it might improve the physical properties and fertility of the soil (Pomares et al., 1984). This is due to the content of nitrogen (N), phosphorus $(\mathrm{P})$, organic matter and other trace elements in wastewater, which thus represents a good source of nutrients for plant growth and promotion of harvest yield and quality (Benitez et al., 2001). This fertiliser effect of wastewater can provide reduced costs in terms of nitrogen and phosphorus mineral fertiliser use, and might also improve the quantitative aspects of crop yield (Wild and Jones, 1991). On the other hand, wastewater might contain undesirable chemical constituents and pathogens that can have negative environmental and health impacts (Papadopulos, 1995).

Some studies have investigated the influence of irrigation with treated wastewater on tomato crop yields, but there remains the need to better define the full effects on the fruit quality parameters and the acceptable levels of biological contamination (Aiello et al., 2007; Christou et al., 2014; Gatta et al., 2014). For this purpose, the present study was designed to evaluate the effects of two water irrigation sources, as the groundwater (GW) control, and treated agro-industrial wastewater (SW), on the main quality parameters and microbiological safety of processing tomato fruit.

\section{Materials and methods}

\section{Experimental field and cultivation practices}

The field trial was carried out with the tomato (Lycopersicon esculentum Mill.) cultivar Manyla (Semillas Fitò, Spain) during the growing season of 2013 (April to September), in an agricultural area of the Apulian region in southern Italy (Stornarella: $41^{\circ} 15^{\prime} \mathrm{N}, 15^{\circ} 44^{\prime} \mathrm{E}$; altitude, $154 \mathrm{~m}$ asl). The tomato plants were grown under a net-house structure, and were covered with an anti-hail net. The experimental site was near to the Fiordelisi agricultural and food manufacturing company, which produces and processes vegetables.

The investigation was carried out in a clay loam soil, with a field capacity $(-0.03 \mathrm{MPa})$ of $31.9 \%$ dry weight $(\mathrm{dw})$, a wilting point $(-1.5$ $\mathrm{MPa}$ ) of $15.3 \% \mathrm{dw}$, and a bulk density of $1.38 \mathrm{Mg} \mathrm{m}^{-3}$.

The tomato seedlings were transplanted into the plots on 5 April, 2013 , in mulched paired rows (40 cm apart) spaced at $250 \mathrm{~cm}$, with the plants at a distance of $30 \mathrm{~cm}$ apart along each single row. The final 
plant density was 2.7 plants $\mathrm{m}^{-2}$. The plants were grown in a vertical setting, using nylon threads disposed between plants collars, and iron wires arranged longitudinally in the direction of the plant rows, and fixed to the upper part of the net-house, at $2.5 \mathrm{~m}$ from the ground.

Two experimental irrigation treatments were applied to the tomato plants, relating to the source of their irrigation water: irrigation with GW (control) and SW. The SW used in this study was taken from the secondary wastewater treatment plant that purifies all of the wastewater produced by the Fiordelisi agricultural and food manufacturing company during their industrial processing of vegetables.

The experiment was laid out as a randomised complete block design, with the two irrigation treatments each replicated three times. A drip irrigation system was used for crop irrigation. The irrigation scheduling was based on continuous measurements of volumetric soil watercontent changes at the effective rooting depth, using frequency domain reflectometry probes (EasyAG, Sentek Sensor Technologies, Stepney $\mathrm{SA}$, Australia). The irrigation was performed every time the available soil moisture was depleted to the threshold value of $40 \%$ (Allen et al. 1998), and at each irrigation, the soil water content of each plot was increased to field capacity. The soil fertilising and pest and weed control were performed according to local management practices, and were the same across the two experimental systems.

Four harvests (HD) were carried out, from July to September, at: 97 $\left(\mathrm{HD}_{1}\right), 118\left(\mathrm{HD}_{2}\right), 137\left(\mathrm{HD}_{3}\right)$ and $160\left(\mathrm{HD}_{4}\right)$ days after transplanting, each on an experimental plot of $20 \mathrm{~m}^{2}$, by picking all of the mature fruit.

\section{Water and tomato fruit analysis}

The GW and SW samples were collected at monthly intervals, to characterise their physico-chemical and microbiological properties. These samples were analysed in triplicate, according to the international methods of the American Public Health Association, the American Water Works Association, and the Water Environment Federation (APHA, AWWA, WEF, 2005). The physico-chemical characterisation included the analysis of: $\mathrm{pH}$, electrical conductivity $\left(\mathrm{EC}_{\mathrm{w}} ; \mathrm{dS} \mathrm{m}^{-1}\right)$, total suspended solids (TSS; $\mathrm{mg} \mathrm{L}^{-1}$ ), biological oxygen demand over 5 days $\left(\mathrm{BOD}_{5} ; \mathrm{mg} \mathrm{L}^{-1}\right)$, chemical oxygen demand (COD; mg L $\left.{ }^{-1}\right)$, ammoniumnitrogen $\left(\mathrm{NH}_{4}-\mathrm{N} ; \mathrm{mg} \mathrm{L}^{-1}\right)$, nitrate-nitrogen $\left(\mathrm{NO}_{3}-\mathrm{N} ; \mathrm{mg} \mathrm{L}^{-1}\right)$, nitrite- nitrogen $\left(\mathrm{NO}_{2}-\mathrm{N} ; \mathrm{mg} \mathrm{L}^{-1}\right)$, phosphorus $\left(\mathrm{PO}_{4}-\mathrm{P} ; \mathrm{mg} \mathrm{L}{ }^{-1}\right)$, sodium $\left(\mathrm{Na}^{+}\right.$; $\left.\mathrm{mg} \mathrm{L}^{-1}\right)$, and calcium $\left(\mathrm{Ca}^{2+} ; \mathrm{mg} \mathrm{L}^{-1}\right)$.

For the microbiological parameters, the GW and SW samples were initially analysed for Escherichia coli using a membrane filtration method, and for Salmonella spp. using the ISO 19250:2013 procedure (IS0, 2013). The bacteriological analysis of the plant and fruit samples included determination of $E$. coli, faecal coliforms, and total heterotrophic counts (THCs). These analyses were conducted by the plate-

Table 1. Main physico-chemical and microbial parameters related to the two irrigation water types considered.

\begin{tabular}{|c|c|c|c|}
\hline \multirow[t]{2}{*}{ Parameter } & \multicolumn{2}{|c|}{$\begin{array}{l}\text { Irrigation } \\
\text { treatment }\end{array}$} & \multirow[t]{2}{*}{ Significance } \\
\hline & GW & SW & \\
\hline \multicolumn{4}{|c|}{ Main physico-chemical characteristics } \\
\hline $\mathrm{NH}_{4}-\mathrm{N}\left(\mathrm{mg} \mathrm{L}^{-1}\right)$ & $0.05 \pm 0.01$ & $2.00 \pm 0.52$ & $* *$ \\
\hline $\mathrm{NO}_{3}-\mathrm{N}\left(\mathrm{mg} \mathrm{L}^{-1}\right)$ & $22.95 \pm 1.00$ & $0.66 \pm 0.15$ & $* * *$ \\
\hline $\mathrm{PO}_{4}-\mathrm{P}\left(\mathrm{mg} \mathrm{L}^{-1}\right)$ & $0.13 \pm 0.01$ & $0.38 \pm 0.04$ & $* *$ \\
\hline $\mathrm{COD}\left(\mathrm{mg} \mathrm{L}^{-1}\right)$ & $18.68 \pm 1.03$ & $36.97 \pm 3.00$ & $*$ \\
\hline $\mathrm{BOD}_{5}\left(\mathrm{mg} \mathrm{L}^{-1}\right)$ & $10.70 \pm 1.25$ & $23.70 \pm 2.00$ & $*$ \\
\hline Electrical conductivity $\left(\mathrm{dS} \mathrm{cm}^{-1}\right)$ & $0.87 \pm 0.01$ & $3.07 \pm 0.20$ & $* * *$ \\
\hline $\mathrm{pH}$ & $7.75 \pm 0.05$ & $7.84 \pm 0.08$ & ns \\
\hline Total suspended solids (mg L $\mathrm{L}^{-1}$ ) & $3.70 \pm 2.28$ & $17.63 \pm 4.17$ & $* *$ \\
\hline $\mathrm{Na}^{+}\left(\mathrm{mg} \mathrm{L}^{-1}\right)$ & $33.47 \pm 0.51$ & $305.74 \pm 6.87$ & $* * *$ \\
\hline $\mathrm{Ca}^{2+}\left(\mathrm{mg} \mathrm{L}^{-1}\right)$ & $79.83 \pm 1.41$ & $80.50 \pm 2.20$ & n.s. \\
\hline \multicolumn{4}{|c|}{ Main microbial characteristics (CFU $100 \mathrm{~mL}^{-1}$ ) } \\
\hline E. coli & 0 & 1560 & $* *$ \\
\hline Fecal coliforms & 17 & 3094 & $* *$ \\
\hline Salmonella spp. & n.d. & n.d. & \\
\hline
\end{tabular}

GW, groundwater; SW, secondary agro-industrial wastewater. *, Statistically significant at $\mathrm{P} \leq 0.05$; **, statistically significant at $\mathrm{P} \leq 0.01$; ${ }^{* * *}$, statistically significant at $\mathrm{P} \leq 0.001$. n.s., not significant; n.d., not detected.

Table 2. Main qualitative traits of the tomato fruit analysis related to the water irrigation treatments and the harvest data.

\begin{tabular}{|c|c|c|c|c|c|c|c|c|c|c|}
\hline \multirow{2}{*}{ Experimental factor } & \multicolumn{10}{|c|}{ Qualitative parameter of the tomato fruit } \\
\hline & $\begin{array}{c}\text { DM } \\
(\% \mathrm{FM})\end{array}$ & $\begin{array}{l}W^{\mathrm{m}} \\
(\mathrm{g})\end{array}$ & $\begin{array}{l}\mathrm{D}^{\mathrm{m}} \\
(\mathrm{cm})\end{array}$ & CI & $\mathrm{pH}$ & $\begin{array}{c}\text { SSC } \\
\left({ }^{\circ} \text { Brix }\right)\end{array}$ & $\begin{array}{c}\mathrm{TA} \\
\left(\mathrm{g} 100 \mathrm{~mL}^{-1}\right)\end{array}$ & $\begin{array}{c}\mathrm{Ca}^{2+} \\
\text { (mg } 100 \mathrm{~g}^{-1} \mathrm{FM} \text { ) }\end{array}$ & $\begin{array}{l}\mathrm{Na}+ \\
\text { (mg } 100 \mathrm{~g}^{-1} \mathrm{FM} \text { ) }\end{array}$ & $\begin{array}{c}\mathrm{NO}_{3}^{-} \\
\left(\mathrm{mg} 100 \mathrm{~g}^{-1} \mathrm{FM}\right)\end{array}$ \\
\hline \multicolumn{11}{|c|}{ Harvest date } \\
\hline $\mathrm{HD}_{1}$ & $6.83 \pm 0.20^{\mathrm{a}}$ & $78.03 \pm 1.73^{\mathrm{a}}$ & $4.99 \pm 0.03^{\mathrm{a}}$ & $1.29 \pm 0.02^{\mathrm{a}}$ & $4.43 \pm 0.03^{\mathrm{a}}$ & $6.3 \pm 0.10^{\mathrm{a}}$ & $0.45 \pm 0.08^{\mathrm{a}}$ & $29.53 \pm 3.71^{\mathrm{b}}$ & $18.07 \pm 0.95^{b}$ & $1.57 \pm 0.32^{b}$ \\
\hline $\mathrm{HD}_{2}$ & $7.36 \pm 0.12^{\mathrm{a}}$ & $75.56 \pm 2.81^{\mathrm{a}}$ & $4.91 \pm 0.05^{\mathrm{a}}$ & $1.04 \pm 0.01^{\mathrm{bc}}$ & $4.40 \pm 0.01^{\mathrm{a}}$ & $6.3 \pm 0.12^{\mathrm{a}}$ & $0.29 \pm 0.04^{b}$ & $49.95 \pm 4.05^{\mathrm{ab}}$ & $19.67 \pm 0.92^{b}$ & $2.88 \pm 0.35^{\mathrm{a}}$ \\
\hline $\mathrm{HD}_{3}$ & $6.92 \pm 0.17^{\mathrm{a}}$ & $62.08 \pm 2.73^{b}$ & $3.49 \pm 0.04^{b}$ & $1.03 \pm 0.02^{c}$ & $4.51 \pm 0.02^{\mathrm{a}}$ & $5.6 \pm 0.08^{b}$ & $0.28 \pm 0.02^{b}$ & $60.77 \pm 7.44^{\mathrm{a}}$ & $21.97 \pm 0.69 \mathrm{~b}$ & $1.55 \pm 0.42^{b}$ \\
\hline $\mathrm{HD}_{4}$ & $8.34 \pm 0.77^{\mathrm{a}}$ & $50.89 \pm 1.96^{\mathrm{b}}$ & $3.21 \pm 0.11^{\mathrm{c}}$ & $1.17 \pm 0.03^{\mathrm{ab}}$ & $4.44 \pm 0.03^{\mathrm{a}}$ & $5.3 \pm 0.19^{b}$ & $0.19 \pm 0.01^{\mathrm{c}}$ & $54.61 \pm 9.22^{\mathrm{a}}$ & $31.50 \pm 1.62^{\mathrm{a}}$ & $1.96 \pm 0.18^{\mathrm{ab}}$ \\
\hline Significance & n.s. & $* * *$ & $* * *$ & $* * *$ & n.s. & $* * *$ & $* * *$ & $*$ & $* * *$ & * \\
\hline \multicolumn{11}{|c|}{ Irrigation treatment } \\
\hline GW & $7.42 \pm 0.42^{\mathrm{a}}$ & $68.57 \pm 3.86^{\mathrm{a}}$ & $4.18 \pm 0.10^{a}$ & $1.12 \pm 0.03^{\mathrm{a}}$ & $4.47 \pm 0.02^{\mathrm{a}}$ & $5.9 \pm 0.15^{\mathrm{a}}$ & $0.31 \pm 0.03^{\mathrm{a}}$ & $54.97 \pm 1.82^{\mathrm{a}}$ & $22.80 \pm 1.82^{\mathrm{a}}$ & $2.21 \pm 0.13^{\mathrm{a}}$ \\
\hline SW & $7.30 \pm 0.26^{\mathrm{a}}$ & $64.70 \pm 3.50^{\mathrm{a}}$ & $4.12 \pm 0.09^{\mathrm{a}}$ & $1.13 \pm 0.04^{\mathrm{a}}$ & $4.45 \pm 0.01^{\mathrm{a}}$ & $5.8 \pm 0.17^{\mathrm{a}}$ & $0.30 \pm 0.03^{\mathrm{a}}$ & $42.47 \pm 1.62^{\mathrm{a}}$ & $23.97 \pm 1.43^{\mathrm{a}}$ & $1.62 \pm 0.32^{b}$ \\
\hline Significance & n.s. & n.s. & n.s. & n.s. & n.s. & n.s. & n.s. & n.s. & n.s. & $*$ \\
\hline \multicolumn{11}{|c|}{ Harvest date $\mathrm{x}$ irrigation treatment } \\
\hline Significance & n.s. & n.s. & n.s. & n.s. & n.s. & n.s. & n.s. & n.s. & n.s. & n.s. \\
\hline
\end{tabular}


count method on tryptone bile X-glucuronide agar, E. coli agar, and tryptone soya agar, respectively (Allen et al., 2004; Wood et al., 2010). Moreover, the tomato plant and fruit samples were also analysed for Salmonella spp.

After the harvesting on the four harvest dates $\left(\mathrm{HD}_{1-4}\right)$, a sample of 10 marketable fruit from each plot from each harvest date were measured for the following: mean weight $\left(\mathrm{W}_{\mathrm{m}} ; \mathrm{g}\right)$, mean diameter (equatorial and longitudinal diameter) $\left(\mathrm{D}_{\mathrm{m}} ; \mathrm{cm}\right)$, soluble solids content of the flesh (SSC; ${ }^{\circ}$ Brix), $\mathrm{pH}$, titratable acidity (TA; g citric acid $100 \mathrm{~mL}^{-1}$ fresh juice; AOAC 1995), dry matter content (DM; \% fruit fresh matter), $\mathrm{a}^{*} / \mathrm{b}^{*}$ ratio (colour index; CI) (Jiménez-Cuesta et al., 1981; Favati et al., 2009), and $\mathrm{Ca}^{2+}, \mathrm{Na}^{+}$and $\mathrm{NO}_{3}{ }^{-}$contents. The $\mathrm{Na}^{+}, \mathrm{Ca}^{2+}$ and $\mathrm{NO}_{3}{ }^{-}$levels were determined by ion-exchange chromatography (Dionex ICS-1100, Dionex Corporation, Sunnyvale, CA, USA).

\section{Statistical analysis}

The data are expressed as means \pm standard error. The data were processed for statistical analysis by unpaired t-tests (water qualitative parameters, bacterial indicators) or by ANOVA procedures (tomato fruit parameters), and differences are considered significant at $\mathrm{P} \leq 0.05$. For the qualitative parameters of the tomato fruit, Bartlett tests confirmed the homogeneity of the variance among the harvest data, so a combined statistical analysis was performed.

\section{Results and discussion}

\section{Water qualitative traits}

Table 1 given the means of the physico-chemical and microbial characteristics of the GW and SW analysed during the experimental trial. Except for $\mathrm{NO}_{3}-\mathrm{N}$, higher values were observed in the SW than the $\mathrm{GW}$, in agreement with other studies (Cirelli et al., 2012; Lopez et al., 2010). Compared to GW, SW was characterised by higher $\mathrm{NH}_{4}-\mathrm{N}$ and $\mathrm{PO}_{4}-\mathrm{P}$, which are strongly related to soil fertility and plant growth, as well as by higher organic matter content (as indicated by the TSS, COD and $\mathrm{BOD}_{5}$ ), $\mathrm{Na}^{+}$and $\mathrm{EC}_{\mathrm{w}}$. In contrast, the $\mathrm{GW}$ was characterised by significantly higher $\mathrm{NO}_{3}-\mathrm{N}$ than the $\mathrm{SW}\left(22.95 \mathrm{mg} \mathrm{L}^{-1}\right.$ vs $\left.0.66 \mathrm{mg} \mathrm{L}^{-1}\right)$. This will be due to the extensive nitrogen fertiliser application in the study area (Gatta et al., 2014), which leads, in turn, to consistent nitrate leaching and diffuse aquifer pollution. Similar $\mathrm{pH}$ and $\mathrm{Ca}^{2+}$ levels were observed for the GW and the SW.

The microbiological qualities of the two irrigation waters were significantly different (Table 1). Indeed, E. coli and Salmonella spp. were not isolated in any of the GW samples, while faecal coliforms were very low in the GW (17 CFU $100 \mathrm{~mL}^{-1}$ ). The SW was characterised by 1560 CFU $100 \mathrm{~mL}^{-1}$ and $3094 \mathrm{CFU} 100 \mathrm{~mL}^{-1}$ for $E$. coli and faecal coliforms, respectively. The SW samples were not, however, positive for Salmonella spp. (Table 1). These SW microbial indicators were typical of secondary effluent that is not subjected to disinfection.

\section{Qualitative traits and microbial pollution of the tomato plants and fruit}

The mean qualitative traits of the tomato fruit in terms of the water irrigation treatments and the harvest date are reported in Table 2. Neither of the experimental factors considered (harvest date, irrigation treatment) showed any significant effects in their interactions.

For the qualitative parameters of the tomato fruit that were analysed, only $\mathrm{NO}_{3}{ }^{-}$content showed significant differences in terms of the water irrigation treatments. The $\mathrm{NO}_{3}{ }^{-}$content of the tomato fruit was significantly higher for the treatments with the GW $\left(2.21 \mathrm{mg} 100 \mathrm{~g}^{-1}\right)$ than the SW (1.62 mg $\left.100 \mathrm{~g}^{-1}\right)$. This will be related to the higher $\mathrm{NO}_{3}-\mathrm{N}$ con-
Table 3. Microbial counts (by plate counts) of the bacterial indicators for the tomato plants and fruit.

\begin{tabular}{lcc} 
Bacterial indicator & \multicolumn{2}{c}{ Irrigation treatment } \\
& GW & SW \\
Plants $\left(\mathrm{CFU} \mathrm{g}^{-1}\right)$ & & \\
E. coli & $<10$ & $<10$ \\
Faecal coliforms & $<10$ & $<10$ \\
Total heterotrophic count & $5941 \pm 1134$ & $3408 \pm 985$ \\
Salmonella spp. & n.d. & n.d. \\
Fruit $\left(\mathrm{CFU} \mathrm{g}^{-1}\right)$ & & \\
E. coli & $<10$ & $<10$ \\
Faecal coliforms & $<10$ & $<10$ \\
Total heterotrophic count & $13,450 \pm 5554$ & $978,325 \pm 599,019$ \\
Salmonella spp. & n.d. & n.d. \\
\hline
\end{tabular}

$\mathrm{GW}$, groundwater; SW, treated agro-industrial wastewaters; n.d., not detected. Data are means \pm standard errors for each analysed trait. For plants: 1 sample per water treatment $\times 3$ replicates $\times 6$ sampling dates; for fruit: 1 sample per water treatment $\times 3$ replicates $\times 4$ sampling dates. None of these data were significantly different between the irrigation treatments $(\mathrm{t}$ test).

tent in the GW than the SW (Table 1). However, it should be noted that the $\mathrm{NO}_{3}{ }^{-}$content in the tomato fruit remained well below the limits of the European guidelines (European Commission, 2011). The mean values of the remaining qualitative parameters (i.e., DM, $\mathrm{W}_{\mathrm{m}}, \mathrm{D}_{\mathrm{m}}, \mathrm{CI}, \mathrm{pH}$, $\mathrm{SSC}, \mathrm{TA}, \mathrm{Ca}^{2+}, \mathrm{Na}^{+}$) were in agreement with the data from other studies (Mahajan and Singh, 2006; Favati et al., 2009; Madrid et al., 2009).

In terms of the harvest date as an experimental factor, only the DM and $\mathrm{pH}$ were not significantly different. Here, the $\mathrm{W}_{\mathrm{m}}$ and $\mathrm{D}_{\mathrm{m}}$ ranged from $78.03 \mathrm{~g}$ to $50.89 \mathrm{~g}$, and from $4.99 \mathrm{~cm}$ to $3.21 \mathrm{~cm}$, respectively, with the highest values for $\mathrm{HD}_{1}$. These data can be explained-considering that the size and shape of a fruit can vary in relation to its position on the plant. Generally, the first fruit of the first truss are larger in size than the rest (Sawhney and Greyson, 1972).

The CI showed the lowest values for $\mathrm{HD}_{3}$ (1.03) and $\mathrm{HD}_{2}$ (1.04); these are probably related to the different levels of radiation that will have been received by the tomato fruit during the cycle. The SSC and TA decreased significantly from the first $\left(\mathrm{HD}_{1}\right)$ to the last $\left(\mathrm{HD}_{4}\right)$ harvest dates, with decreases from 6.3 to $5.3^{\circ}$ Brix and from 0.45 to $0.19 \mathrm{~g}$ $100 \mathrm{~mL}^{-1}$, respectively. In general, in the course of the trial, the SSC and TA were consistent with data from other field experiments on tomato (Richardson et al., 2006; Madrid, 2009).

The $\mathrm{Na}^{+}$content of the tomato fruit increased to the last harvest date, varying from $18.07 \mathrm{mg} 100 \mathrm{~g}^{-1}\left(\mathrm{HD}_{1}\right)$ to $31.50 \mathrm{mg} 100 \mathrm{~g}^{-1}\left(\mathrm{HD}_{4}\right)$, and thus showing a $40 \%$ increase from $\mathrm{HD}_{1}$ to $\mathrm{HD}_{4}$. This increase in $\mathrm{Na}^{+}$was probably due to the high $\mathrm{Na}^{+}$contents in the irrigation water source (particularly in the SW), and consequently in the soil (data not shown). A similar behaviour was observed for the $\mathrm{Ca}^{2+}$ content.

The plant analysis (including the shoots and leaves) were characterised by faecal indicators below the sensitivity threshold of the count method, and THC was in the range of $10^{3} \mathrm{CFU} \mathrm{g}^{-1}$ for all samples, without significant differences between the GW and SW data (Table 3). Also, the tomato fruit microbial quality was not significantly different between the GW and SW treatments, as Salmonella spp. were not isolated in any of the samples, and the faecal indicators were all below 10 $\mathrm{CFU} \mathrm{g}^{-1}$ (Table 3). THC in the tomato fruits were in the range of $10^{4}$ $\mathrm{CFU/g}$, without significant differences between $\mathrm{GW}$ and SW. The higher level with respect to the plant (leaf and shoot) is due to the maturation of the fruit and the higher level of sugars on tomato skin that could benefit the epiphytic bacteria (Mercier and Lindow, 2000).

Our results are in agreement with other recent studies that have shown low impact for the microbial contamination of tomato crops irrigated by treated secondary wastewaters (Cirelli et al., 2012; Christou et 
al., 2014; Gatta et al., 2014). This will be due to several factors, such as: the drip irrigation system and mulching system adopted, and the effects of UV radiation exposure on the fruit and leaf surfaces.

\section{Conclusions}

The principal objective of this researcher was to evaluate the use of agro-industrial wastewater in a closed circle system where a food manufacturing company produces and processes tomatoes. More specifically, the study was aimed at examining the impact of treated agro-industrial wastewaters, used for irrigation of tomato crop, on quality and safety of the fruits.

The main results can be summarised as follows: i) the most important morpho-qualitative parameters of processing tomato fruit (i.e., $\mathrm{W}_{\mathrm{m}}$ and $\mathrm{D}_{\mathrm{m}}$ of the fruit, TA, SSC, DM, pH, CI) for the GW and SW irrigation treatments are in agreement with the literature; and ii) despite higher levels of faecal indicators in the SW, the microbiological quality of the harvested fruit was not affected.

Our research showed that irrigation of tomato plants with agroindustrial treated wastewater did not negatively affect the main quality parameters of the tomato fruits. However, we will continue to monitor the effects of treated wastewater use on fruit quality in terms of the long-term effects of this irrigation source application on the agroecosystem.

\section{References}

Aiello R, Cirelli GL, Consoli S, 2007. Effect of reclaimed wastewater irrigation on soil and tomato fruits: a case study in Sicily (Italy). Agric. Water Manage. 93:65-72.

Allen MJ, Edberg SC, Reasoner DJ, 2004. Heterotrophic plate count bacteria - what is their significance in drinking water? Int. J. Food Microbiol. 92:265-74.

Allen RG, Pereira LS, Raes D, Smith M, 1998. Crop evapotraspiration guidelines for computing crop water requirements. Irrigation and Drainage Paper No 56. Food and Agriculture Organisation of the United Nations (FAO), Rome, Italy.

APHA, AWWA, WEF, 2005. Standard methods for the examination of water and wastewater, XX ed. American Public Health Association, Washington, DC, USA.

AOAC (Association of Official Analytical Chemists), 1995. Official methods of analysis, 16th ed. AOAC, Washington, DC, USA, p 16.

Benitez E, Romero M, Gomez M, Gallardolaro F, Nogales R, 2001. Biosolid and biosolid ash as sources of heavy metals in plant-soil system. Water Air Soil Pollut. 132:75-87.

Christou A, Maratheftis G, Eliadou E, Michael C, Hapeshi E, Fatta-kassinos D, 2014. Impact assessment of the reuse of two discrete treated wastewaters for the irrigation of tomato crop on the soil geochemical properties, fruit safety and crop productivity. Agric. Ecosyst Environ. 192:105-14.

Cirelli GL, Consolia S, Licciardello F, Aiello R, Giuffrida F, Leonardi C, 2012. Treated municipal wastewater reuse in vegetable production. Agric. Water Manage. 104:163-70.

European Commission, 2011. Commission Regulation (EU) No 1258/2011 of 2 December 2011 amending Regulation (EC) No 1881/2006 as regards maximum levels for nitrates in foodstuffs. In: Official Journal L 320, 3/12/2011, pp 15-17.

Favati F, Lovelli S, Galgano F, Miccolis V, Di Tommaso T, Candido V, 2009. Processing tomato quality as affected by irrigation scheduling. Sci. Hort. 122:562-71.

Gatta G, Libutti A, Gagliardi A, Beneduce L, Brusetti L, Borruso L, Disciglio G, Tarantino E, 2014. Treated agro-industrial wastewater irrigation of tomato crop: effects on qualitative/ quantitative characteristics of production and microbiological properties of the soil. Agric. Water Manage. 149:33-43.

IS0 (International Standard Organisation), 2013. IS0 19250:2013. Water quality - Detection of Salmonella spp. Available from: http://www.iso.org/iso/catalogue_detail?csnumber $=43448$

Jimenez-Cuesta M, Cuquerella J, Martinez-Javaga JM, 1981. Determination of color index for citrus fruits degreening. Proc. Int. Sot. Citricult. 2:750-3.

Lopez A, Pollice A, Laera G, Lonigro A, Rubino P, 2010. Membrane filtration of municipal wastewater effluents for implementing agricultural reuse in southern Italy. Water Sci. Technol. 625:1121-8.

Madrid R, Barba EM, Sanchez A, Garcia AL, 2009. Effects of organic fertilizers and irrigation level on physical and chemical quality of industrial tomato fruit (cv. Nautilis). J. Sci. Food Agric. 89:2608-15.

Mahajan G, Singh KG, 2006. Response of greenhouse tomato to irrigation and fertigation. Agric. Water Manage. 84:202-6.

Mercier J. Lindow SE. 2000. Role of leaf surface sugars in colonization of plants by bacterial epiphytes. Appl. Environ. Microbiol. 66:669-74.

Papadopoulos I, 1995. Wastewater management for agriculture protection in the Near East Region, Technical Bulletin. FAO, Regional Office for the Near East, Cairo, Egypt.

Pomares F, Roca J, Tarazona F, Estale M, 1984. Aerobically digested sewage sludge as $\mathrm{N}$ and $\mathrm{P}$ fertilizer. In: Commission of the European Communities, Processing and use of sewage sludge. Reidel, Dordrecht, pp 313-315.

Richardson C, Hobson GE, 2006. Compositional changes in normal and mutant tomato fruit during ripening and storage. J. Sci. Food Agric. 40:245-52.

Sawhney VK, Greyson RI, 1972. On the imitiation of the inflorescence and floral organs in the tomato Lycopersicon esculentum). Can. J. Bot. 62:1493-5.

Wild SR, Jones KC, 1991. Organic contaminants in wastewaters and sewage sludges: transfer to the environment following disposal. In: K.C. Jones (ed.), Organic contaminants in the environment - environmental pathways and effects. Elsevier, London, UK, pp 133-158.

Wood JD, Bezanson GS, Gordon RJ, Jamieson R, 2010. Population dynamics of Escherichia coli inoculated by irrigation into the phyllosphere of spinach grown under commercial production conditions. Int. J. Food Microbiol. 143:198-204. 